\title{
Evaluation of the balneability of Formigueiro beach in the municipality of Porto Nacional/TO
}

This study was carried out to evaluate the conditions of water balneability that covers the Formigueiro beach, located in the São João river basin, in the municipality of Porto Nacional, located in the state of Tocantins, throughout the months of February and March 2020. The same was done by collecting samples in the field and then these samples were taken for laboratory analysis from the limits of fecal coliforms, in which it provided us to evaluate the water conditions, which according to CONAMA resolution no274/00, resolution in which it establishes the quality criteria for water use, is suitable for balneability purposes.

Keywords: Balneability; Analysis; Quality.

\section{Avaliação da balneabilidade da praia do Formigueiro no município de Porto Nacional/TO}

Este estudo foi realizado com o objetivo de avaliar as condiç̃̃es de balneabilidade das águas que cobrem a praia do Formigueiro, localizada na bacia do rio São João, no município de Porto Nacional, localizado no estado do Tocantins, ao longo dos meses de fevereiro e março de 2020. mesmo foi feito coletando amostras em campo e a seguir essas amostras foram retiradas para análise laboratorial a partir dos limites dos coliformes fecais, em que nos proporcionou avaliar as condições da água, que segundo a resolução CONAMA no 274/00, resolução na qual estabelece os critérios de qualidade para o uso da água, é adequado para fins de balneabilidade.

Palavras-chave: Balneability; Análise; Qualidade.

Topic: Uso de Recursos Naturais

Reviewed anonymously in the process of blind peer.
Received: $13 / 07 / 2020$

Approved: 22/10/2020
Juliano Paulino Franco

Instituto Tocantinense Presidente Antônio Carlos, Brasil

http://lattes.cnpq.br/8928912545221181

jullianofranco@hotmail.com

Ângelo Ricardo Balduino

Instituto Tocantinense Presidente Antônio Carlos, Brasil

http://lattes.cnpq.br/8475669590774317

http://orcid.org/0000-0002-7082-2566

angelo@ifto.edu.br

\section{Referencing this:}

FRANCO, J. P.; BALDUINO, Â. R.. Evaluation of the balneability of Formigueiro beach in the municipality of Porto Nacional/TO. Natural Resources, v.10, n.3, p.162-167, 2020. DOI: http://doi.org/10.6008/CBPC2237-9290.2020.003.0016 


\section{INTRODUCTION}

This study has fundamental importance for the community of Porto Nacional/TO, beacause it is through it that we will be able to analyze the water quality of Formigueiro beach, if it is suitable or not, for primary contact recreation.

As Bacci et al. (2008) have said, that water is very important for the maintenance of life on the planet, and, therefore, to talk about water, in its various proportions, it means to talk about the survival of the human species, preservation and balance of biodiversity and dependency relations between living beings and natural environments. The existence, or lack of water writes history, creates cultures and habits, determines the occupation of territories, wins battles, extinguishes and gives life to species, defines the future of generations.

According to ANA (2018), it is estimated that $97.5 \%$ of the water present in the world is salty and it is not suitable for our direct consumption or for plantation irrigation. If it is considered $2.5 \%$ of fresh water, most of it (69\%) is difficult to access because it is located in glaciers, $30 \%$ are groundwater (stored in aquifers) and $1 \%$ is in rivers. However, the use of this good needs to be reflected so that it does not harm any of the multiple uses it has for human life.

Among these multiple uses is the balneability, which according to CETESB (2018), is the quality of water for primary contact recreation purposes, being fundamental for its analysis the application of objective criteria. These criteria are based on the densities of microorganisms that indicate fecal contamination to be analyzed and their results compared to pre-established models, so that there can be the verification of the conditions of balneability of a chosen location.

The criteria are based on CONAMA RESOLUTION No. 274 of November 29, 2000, which defines the balneability parameters in Brazil, so that it has a control of the quality of the water that will meet the people.

Water bodies contaminated by domestic sewage when they reach the waters of the beaches can expose bathers to pathogenic microorganisms such as viruses, bacteria, fungi, protozoa and helminth eggs. Children, the elderly, or people with low immunity are the most likely to develop diseases or infections after contact with these waters (CETESB, 2018).

Because of this, basic sanitation greatly influences the proliferation of bacteria and water diseases. Without basic sanitation, the population is exposed to the contamination of water resources, which is its main source of capture, due to the simultaneous coexistence between the need to obtain the resource and at the same time the lack of knowledge of the risks arising from the direct dumping of its waste on surface water sources (ROHDEN, 2009).

With this it is necessary to perform laboratory analyses, in which we can find several types of bacteria among them The Escherichia coli that is present in fecal coliforms, which process diseases through the feces of people or animals. According to CONAMA RESOLUTION No. 274 (2000), the first article says that escherichia coli is a bacterium that is part of the Enterobacteriaceae group, defined by the existence of $\beta$ galactosity and $ß$-glicuronidase enzymes. It propagates in a complex medium at $44-45^{\circ} \mathrm{C}$, it ferments lactose 
and lyitol with acid and gas generation and it generates indole from the amino acid tryptophan. This bacterium is very present in human and animal excrement, and it can be found in sewage, effluents, natural waters and soils that have been exposed to recent fecal contamination.

The objective of this work is to evaluate the water quality of Formigueiro Beach, located in the São João River Basin in Porto Nacional - TO, for balneability use, according to CONAMA Resolution 274/2000. Through the study of laboratory samples; correlate the results obtained in the period of this study with the parameters specified by Resolution CONAMA 274/2000; classify the conditions of the bath water, analyzing if they are in accordance with environmental legislation.

\section{METHODOLOGY}

\section{Study Area}

The place where this research was carried out was Formigueiro Beach, located in the municipality of Porto Nacional, in the Jardim Querido sector, located in the São João river basin. The municipality of Porto Nacional is in the central region of the state of Tocantins, it has approximately $64 \mathrm{~km}$ from Palmas, capital of the state, with an area of $4,446 \mathrm{~km}^{2}$. It is estimated that the city has a population of 53,010 inhabitants (IBGE, 2019).

The Formigueiro baeach is located between the parallels $10^{\circ} 46^{\prime} 43^{\prime \prime}$ and $20^{\circ} 41^{\prime} 20^{\prime \prime}$ south latitude and between the meridians $48^{\circ} 14^{\prime} 16^{\prime \prime}$ and $48^{\circ} 24^{\prime} 51^{\prime \prime}$ west longitude, southeast of the municipality of Porto Nacional, with an area of $82 \mathrm{~km}^{2}$, with its mouth within the urban area, being a direct contributor to the Tocantins River.

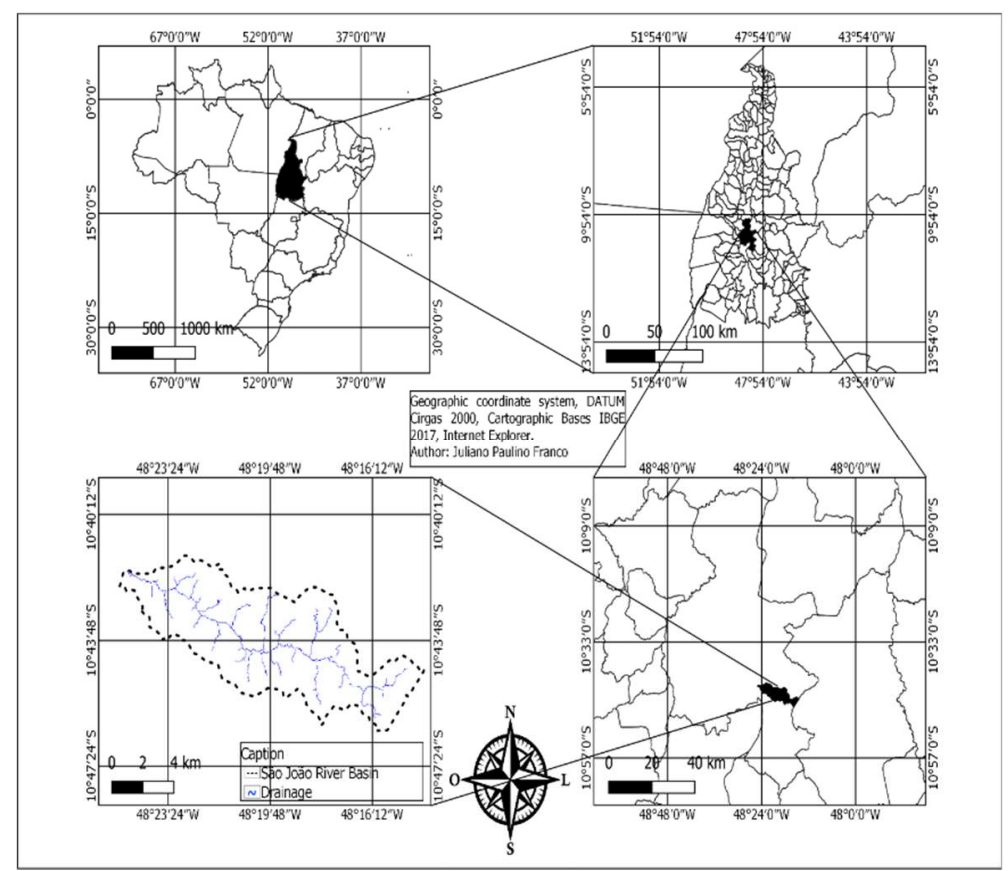

Figure 1: Location map of the São João River Basin

\section{Sample collection procedure}

In this project, the monitoring was carried out during the months of February and March, totaling a 
period of six weeks. The point was demarcated through the global positioning system (GPS navigation model GARMIN-60CSx), with the knowledge that the definition of the sampling point will be performed following the parameters contained in the NBR-9897, which goes directly to the sampling planning of liquid effluents and receiving bodies. In the figure below we have a view of the collection point (PI) of Formigueiro Beach in the São João River Basin (Figure).

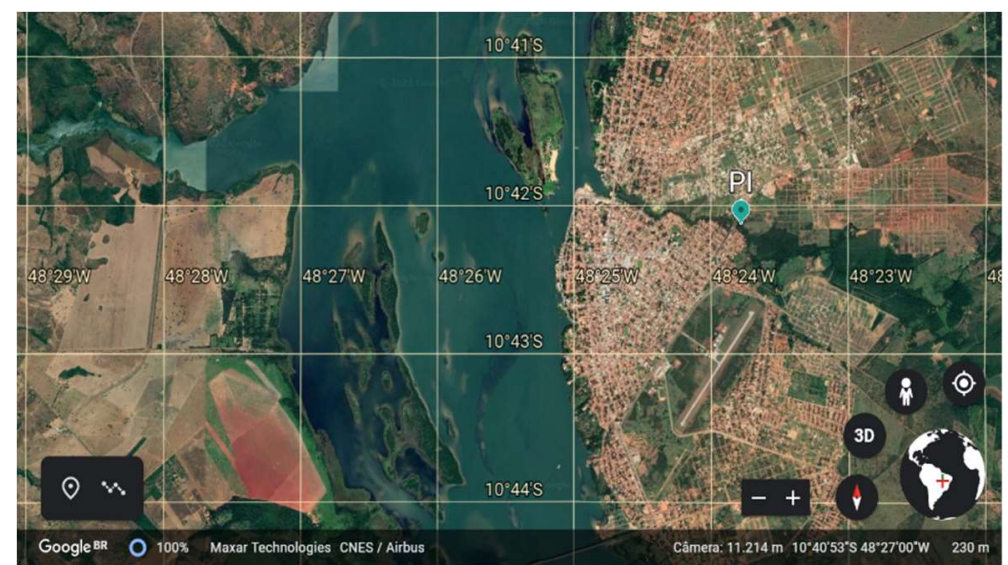

Figure 2: Collection point of Formigueiro Beach in Porto Nacional - Tocantins Source: Google Earth (2020).

The samples were collected weekly, at the point (PI), sterilized glass containers of $100 \mathrm{ml}$ were used, approximately $25 \mathrm{~cm}$ deep. The chosen point for collection was selected according to criteria established by Conama $\mathrm{N}^{0} \cdot 274 / 2000$, following Art. 50, which says that the point will be where to find the largest concentration of people bathing on the beach.

In order to collect the material for data analysis, disposable gloves and sterilized bottles were used, and the samples collected in the field will be stored in a thermal box with ice and then transported to the IFTO chemistry laboratory.

\section{Laboratory analysis method}

The collected samples were transported to the IFTO laboratory - Campus Porto Nacional, from there microbiological analyses on the $E$. coli group were initiated, based on the collilert technique according to the methodology described by Standard Methods.

The Colilert method is widely used in this type of research. The culture medium (Colilert enzyme) comes in the right amount for the analysis of $100 \mathrm{ml}$ of water; each enzyme will be added to the bottle of $100 \mathrm{ml}$ with the sample that was collected and stirred until the complete dilution of the granules. After that, the solution was incubated at $35^{\circ} \mathrm{C}$ in a laboratory oven for 24 hours.

\section{Balneability}

The waters are classified according to CONAMA Resolution $N^{\circ} \cdot 274 / 2000$, in proper (excellent, very good or satisfactory) and improper, the balneability uses the parameter of the number of Escherichia coli, according to Table 1. 
Table 1: Framework for bathing conditions.

\begin{tabular}{|l|l|}
\hline CATEGORY & ESCHERICHIA COLI LIMIT FOR 100ml \\
\hline EXCELLENT & Maximum of 200 in $80 \%$ or more of samples \\
\hline VERY GOOD & Maximum of 400 in $80 \%$ or more of samples \\
\hline SATISFACTORY & Maximum of 800 in $80 \%$ or more of samples \\
\hline IMPROPER & Above 800 in more than $20 \%$ of samples \\
\hline IMPROPER & Above 2000 to the value indicated in the last sampling \\
\hline
\end{tabular}

Source: CONAMA (2000)

\section{RESULTS AND DISCUSSION}

The monitoring of water quality of this study occurred during the months of February and March of 2020 , in the period of rain and drought. During the rainy season, the water presented a dark coloration due to the movement of solids to the riverbed. In the period of drought, the water presented a transparent coloration. However, the color of the water does not indicate contamination, as it can exhibit a transparent color and it still be contaminated.

After all the analyses, all the water samples exhibited a yellow coloration and fluorescence aspects, proving the presence of bacteria from the total coliform group and $E$. coli. The results obtained in the water samples were classified according to CONAMA Resolution 274 of 2000 , which defines that when in $80 \%$ or more of a set of samples obtained in each of the five weeks, a maximum of 800 Escherichia coli is found, the waters are considered proper and falls into the category of 'satisfactory' for balneability purposes. The result obtained in the $3^{\text {rd }}$ week (06/03), because it was very close to 400 it was considered as above 400 , thus justifying the classification as satisfactory. The graph 1 shows the results of $E$. coli bacterial analyses. Present at the monitored point.

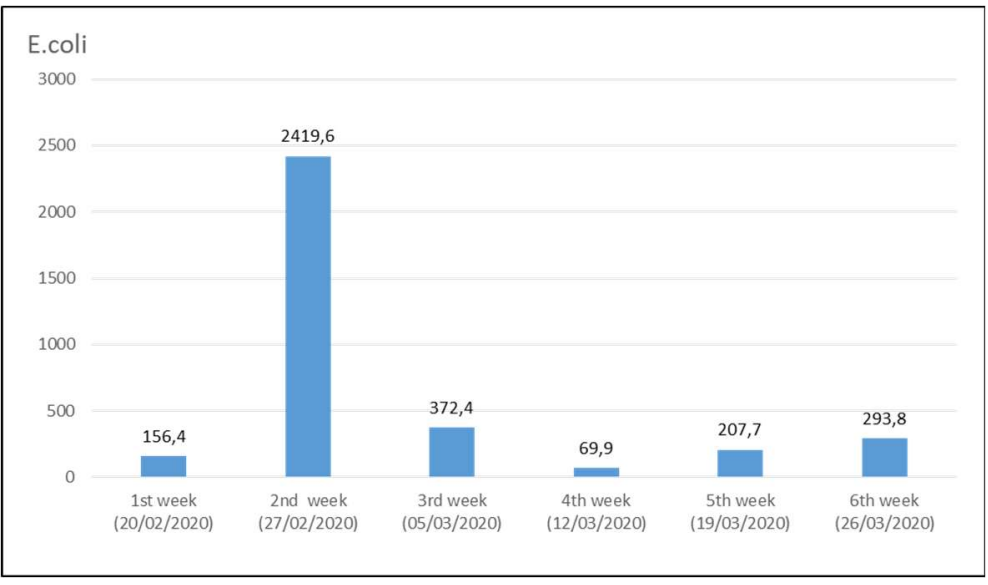

Graph 1- Overall result of Escherichia coli analyses.

The results presented obtained a great variation, from 69.9 to more than 2,419.6 NMP/100 and an average value of $586.6 \mathrm{NMP} / 100$. The highest $e$.coli value analyzed was observed in the $2^{\text {nd }}$ week $(02 / 27)$ and the lowest value in the $4^{\text {th }}$ week $(03 / 12)$. It was observed that the highest presence of Escherichia coli occurred during the period in which there was high rainfall. The rain contributed to the increase in the contamination of the spring, due to the fact that the rainwater drains through the soil carry with it, impurities from the solid waste from animal feces and toxic substance found on the surface of the earth to the river bed.

The results obtained showed a worsening in water quality when compared to Reis et al. (2019), where 
it obtained results ranging from 45.8 to $55.8 \mathrm{NMP} / 100 \mathrm{ml}$, the analysis period of this was from August to December 2018, this demonstrates that in just over a year the water suffered a significant increase in the number of Escherichia Coli. However, if we compare with Lima et al. (2018), where they obtained all the results above 2,419.6 MPN/100 ml, in the period from November 2017 to April 2018, we obtained a great decrease in the number of Escherichia coli.

Finally, it was found that even with high levels of presence of Escherichia coli, the water meets the criteria established by CONAMA Resolution 274 of 2000 as proper for balneability purposes, however we should be on alert because its classification in the category proper was very bad.

\section{CONCLUSIONS}

The water of Formigueiro beach is widely used by the population, whether for bathing, leisure or for economic purposes such as car wash, tank trucks and among other multiple uses. So, you should use water more consciously, avoiding its contamination, because it belongs to everyone. Due to the results obtained in the period of the present study regarding the condition of primary contact balneability, it is concluded that even presented high rates of presence of Escherichia coli, the water of Formigueiro beach, in the são João river basin meets the criteria established by CONAMA resolution 274 of 2000 as its own in the category of satisfactory for balneability purposes.

It is notorious that the beach does not have any information device for bathers, either water quality or on the recommendations for the use of it, it is recommended that the competent bodies provide the signaling of the site.

\section{REFERENCES}

ANA. Agência Nacional de Águas. Água no Brasil, água no mundo: situação da água no mundo. Brasília: ANA, 2018.

BACCI, D. L. C.; PATACA, E. M.. Educação para a água. Estudos Avançados, v.22, n.63, 2008.

CETESB. Companhia de Tecnologia de Saneamento Ambiental. Relatório de Qualidade das Águas Litorâneas no Estado de São Paulo: Balneabilidade das Praias. São Paulo: CETESB, 2018.

CONAMA. Conselho Nacional do Meio Ambiente. Resolução n. $\mathbf{2 7 4}$ de $\mathbf{2 9}$ de novembro de 2000: Define os critérios de balneabilidade em águas brasileiras. Brasília: CONAMA, 2000.

IBGE. Instituto Brasileiro de Geografia e Estatística. Ministério do Planejamento, Orçamento e Gestão. Cidades@: Porto Nacional. Brasília: IBGE, 2019.
LIMA, L. D. S. C.; BALDUINO, Â. R.; OLIVEIRA, C. S.. Avaliação das condições de balneabilidade da Praia do Formigueiro na bacia hidrográfica do Ribeirão São João no município de Porto Nacional, Tocantins. In: FÓRUM AMBIENTAL, 14. Anais. Alta Paulista, 2018.

REIS, J. E.; MENDES, A.; BALDUINO, BALDUINO, Â. R. Evaluation of Water Quality for Bathing Conditions in Formigueiro Beach- Porto Nacional - Tocantins. International Journal of Advanced Engineering Research and Science (IJAERS), v.6, n.5, 2019.

ROHDEN, F.. Monitoramento microbiológico de águas subterrâneas em cidades do Extremo Oeste de Santa Catarina. Ciência \& Saúde Coletiva, v.14, n.6, p.2199-2203, 2009. 